\title{
THE EFFECT OF AL-BAYAN METHOD AND COGNITIVE DEVELOPMENT ON READING THE BEGINNING OF THE LETTERS HIJAIYAH CHILDREN OF GROUP B IN STATE KINDERGARTEN (TK) PEMBINA RANTAU, ACEH TAMIANG DISTRICT
}

\author{
Zakiah Assidiki 1 \\ State University of Medan, Indonesia \\ Email : kiahassidiki@gmail.com \\ Sri Milfayetty ${ }^{2}$ \\ State University of Medan, Indonesia \\ Evi Eviyanti ${ }^{3}$ \\ State University of Medan, Indonesia
}

\begin{abstract}
The aims of this research are (1) to determine the effect of the ability to read the beginning of hijaiyah letters taught by the Al-Bayan method compared to children who are taught by the Iqra' method at the Pembina Rantau State Kindergarten, Aceh Tamiang Regency. Children who have high cognitive development are higher than children with low cognitive development. (3) Knowing the interaction between the Al-Bayan Method and cognitive development on the ability to read the initial hijaiyah letters of group $B$ children in TK Negeri Pembina Rantau, Aceh Tamiang Regency. Data analysis used the Tuckey-test. The results of the study show that (1) There is an influence on the ability to read the beginning of the hijaiyah letters taught by the Al-Bayan method compared to children who are taught by the Iqra' method at the Pembina Rantau State Kindergarten, Aceh Tamiang Regency. Where the results of reading the initial hijaiyah letters of students who are taught using the AlBayan learning method with an average value of 67.00 are higher than students who are taught using the lqra' learning method with an average value of 54.50. (2) There is an effect of reading results of children who have higher cognitive
\end{abstract}


development than children with low cognitive development. Where the average value of the results of reading the initial hijaiyah letters of students with high cognitive development is 65.50, while the average value of the results of early reading of the hijaiyah letter of students with low cognitive development is 58.00. (3) There is a significant interaction between learning methods and students cognitive development on the results of reading the beginning of hijaiyah letters that have cognitive development in group $B$ in state kindergarten Pembina Rantau. Where there is an interaction with $F_{\text {count }}(20.01)>F_{\text {table }}(4.96)$.

Keywords: Al-Bayan Method, Cognitive Development, beginning of the letters hijaiyah

\section{A. Introduction}

Early Childhood Education is education organized with the aim of facilitating the growth and development of children as a whole or emphasizing on developmentall aspects of the child's personality. Therefore, Early Childhood Education institutions need to provide various activities that can develop various aspects of development such as: cognitive, language, social, emotional, physical, and motoric. Based on Article 1 Point 14 of Law No. 20 of 2003 Early Childhood Education is a coaching effort aimed at children from birth to the age of six which is carried out through the provision of educational stimuli to assist physical and spiritual growth and development so that children have readiness in entering further education.

Learning to read hijaiyah letters is part of the Arabic language and the first step in learning to read Arabic, because hijaiyah letters isa collection of Arabic letters to switch the lafadz script, reading or writing from one letter to another. This letter is used in the Qur'an. Syarbini and Al-Kautsar (2010:2), with children understanding and understanding Hijaiyah letters, children will be able to understand the meaning and meaning of the holy book Al-Qur'an which is written in Arabic. 
The development of reading hijaiyah letters requires a learning method. One of the benefits of using the learning method is that it can explain the message so that it candirectchildren's attention and motivate children to take part in learning. For early childhood learning, the use of methods plays an important role, because the principles of early childhood learning are concrete, meaning that children are expected to learn something for real (Zamani, Zaki, 2014). This concrete principle implies the need for a method to be used as a channel for delivering messages from teachers to children so that messages can be well received. The thing that needs serious attention is learning the best method of teaching the Koran to children, where there are some of the best methods of teaching the Koran to children, one of which is the AlBayan method (Putra and Dwi 2012).

Al-Bayan from the Arabic word that is bright, real, information, according to Yunus (1986:75). and Al-Bayan defines it as 1), real, bright, well-spoken. 2), explaining, meaning that the hadith serves to explain the contents of the Qur'an. 3), one of the names of the Qur'an which means light. 4), the branch of balaghah that discusses how to compose, and pronounce a sentence so that the sentence is clear, bright, easy to understand and impressive. El-Bantany (2014:101). The Al-Bayan method was discovered by Surasman who was then introduced to the public in 2008. For 12 years, the Al-Bayan method has continued to develop. The first time it appeared, it was given the name "the practical key to reading the Qur'an properly and correctly". This method is taught for the first time at TKA or TPA. Then it changed its name to "Practical key to Reading the Qur'an properly and correctly. Later, the name was changed to "The Human Method of Practical Keys to Reading the Al-Qur'an Good and Correct" and finally named the Al-Bayan Method, so the Al-Bayan method 
is a method that explains how to quickly learn the Qur'an by using the AlBayan method. good and correct reading according to the science of recitation, arranged systematically and assisted by the Indonesian version, and can be understood and impressive (Surasman, 2009).

The advantages that can be taken from learning using the ALBayan Method include: 1) The AL-Bayan method uses the age level and number of meetings as a benchmark. OnmeetingFinally, students will be able to read the Qur'an correctly and fluently, master long-short readings, reverberation readings (gunnah) and long laws (mad); 2) Aimed at TK B school age children; 3 ) In accordance with the characteristics of early childhood where the AL-Bayan method usesmediawith attractive pictures and colors for children; 4) Using Talaqqi and Musyafahah (through meetings and conversations); 5) The lessons are systematically arranged, where 10 meetings are to master reading and 11 meetings are to master the correct way of reading with tajwid and are equipped with the help of the Indonesian version of how to read and; 6) Illustrations that visualize hijaiyah letters such as letters (alif) are connected to pictures (apple), this can be linked to Montessori theory such as, letter (a) is connected to a picture (chicken) (Surasman, 2009; Helmawati, 2018).

The ability to read children's hijaiyah letters is also not only formed based on methods. But by looking at the child's way of thinking and reasoning, it also really determines the ability to read hijaiyah letters, namely by developmentcognitivechildren (Rakimahwati, 2012). Cognitive is behavior that causes people to gain knowledge or what is needed to use knowledge (Suhada, 2016). Cognitive development shows the development of how children think to solve various problems that can be used as a benchmark for intelligence growth. Patmonodewo (2003:27). 
Children who have low cognitive power tend to be slow in readHijaiyah letters due to the absence of stimulation provided by the environment to children. While children who havepower high cognitive will be easy to read Hijaiyah letters due to the stimulation given from the environment to the child (Suryana, 2016)..

\section{B. Method}

This type of research is an experimental research with a $2 \times 2$ factorial design. This research was conducted in Overseas Builder State Kindergarten huhng has its address at Jl. Jl. Alur Cucur, Rantau District, Aceh Tamiang Regency. The samples in this study were study groups B1 and B2, where study group B1 with 20 children as the experimental class were taught by the Al-Bayan Method and group B2 with 20 children as the control class taught by the Iqra' method. Data collection techniques using tests. The test technique was used to obtain data on the ability to read the initial hijaiyah letters. Hypothesis testing was carried out with the Two Way Anova test with a significant level of 0.05 .

\section{Finding and Discussion}

\section{Result}

a. Result Data Ability Reading Hijaiyah Letter Recognition Students who are taught Using the Al-Bayan Method

Based on data obtained from the post-test results of students reading skills who were taught using the Al-Bayan method, data distribution frequencyin the attachment can be described as follows: the average value $(X)$ is 67 ; variance $=201.05$; standard deviation $(S D)=14.18$; maximum value $=90 ;$ minimum value $=40$ with a range of values $=50$. Based on these values, a histogram of group data can be formed as 
follows:

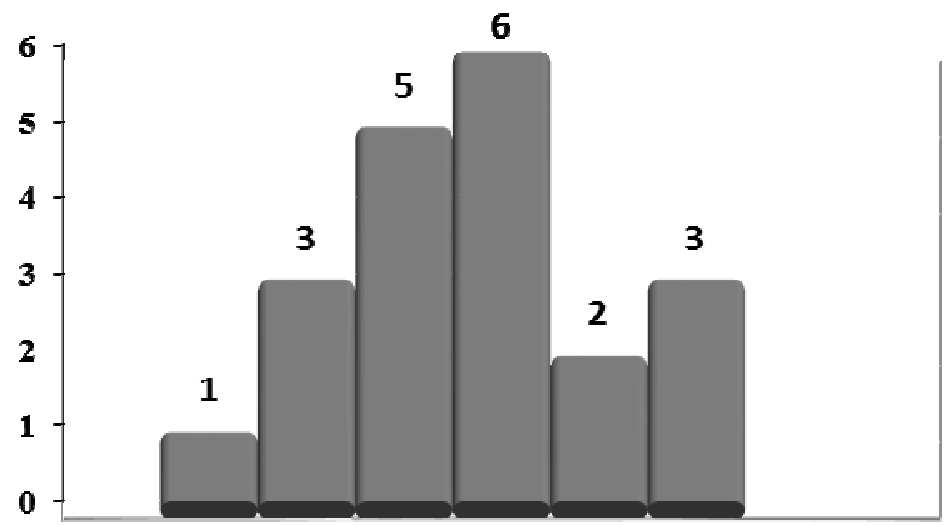

Figure 1. Histogram of Students Reading Ability Recognition of Hijaiyah Letters taught Using the Al-Bayan . Method

b. Result Data Ability Reading Hijaiyah Letter Recognition Students who are taught Using the Iqra' Method

Based on the data obtained from the post-test results of the students ability to read the introduction of hijaiyah letters, they were taught to use methodlqra', the frequency distribution data in the appendix can be described as follows: the arithmetic mean ( $X$ ) is 54.50; variance $=141.84 ;$ standard deviation $(S D)=11.91 ;$ maximum value $=80$; minimum value $=40$ with a range of values (Range) $=40$. Based on these values, a histogram can be formed as follows:

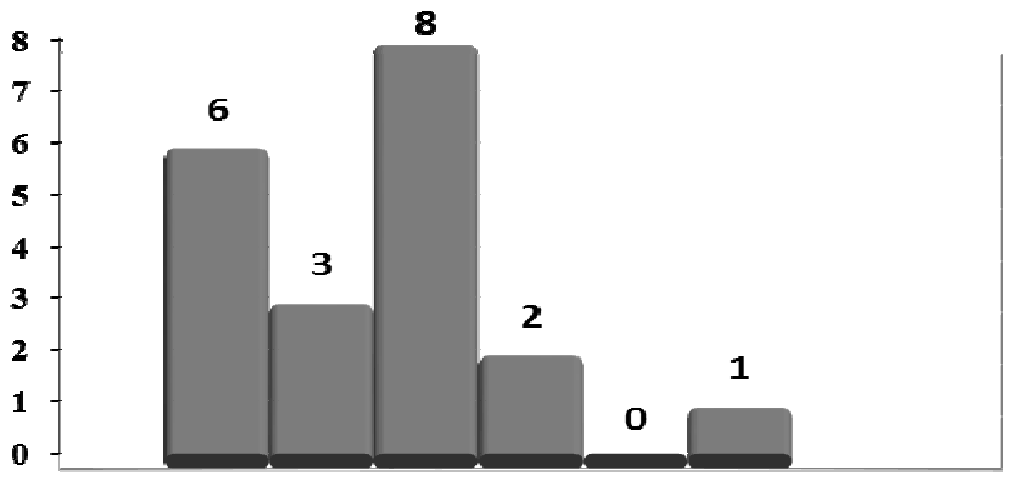


Figure 2. Histogram of Data Results of Hijaiyah Letter Recognition Results of Students Taught Using the Iqra' Method

c. Data on the Results of Reading Ability to Recognize Hijaiyah Letters for Students who have Development High Cognitive

Based on the data obtained from the posttest results of the ability to read the introduction of hijaiyah letters of students who have high cognitive development, the frequency distribution data in the appendix can be described as follows: the arithmetic mean value $(X)$ is 65.50; variance $=236.58 ;$ standard deviation $(S D)=15.38 ;$ maximum value $=90$; minimum value $=40$ with a range of values $=50$. Based on these values, a histogram of group data can be formed as follows:

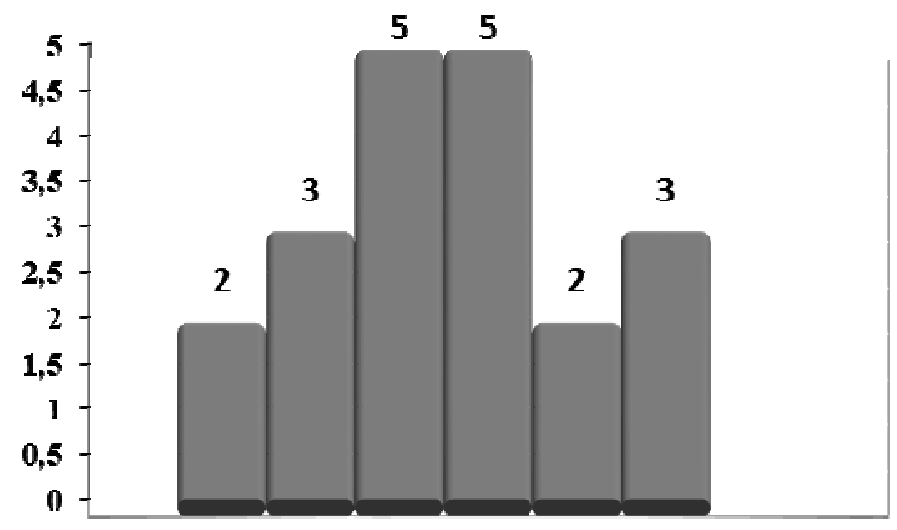

Figure 3. Histogram of the Results of Hijaiyah Letter Recognition of Students with High Cognitive Development

d. Data Results of Hijaiyah Letter Recognition Reading Ability Students Who Have Low Cognitive Development (B2)

Based on the data obtained from the posttest results of the ability to read the introduction of hijaiyah letters of students who have low cognitive development, the frequency distribution data in the appendix 
can be described as follows: the arithmetic mean $(\mathrm{X})$ is 58 ; variance $=$ 195.79; standard deviation $(S D)=13.99$; scoremaximum $=90$; minimum value $=40$ with a range of values $=50$. Based on these values, a histogram of group data can be formed as follows:

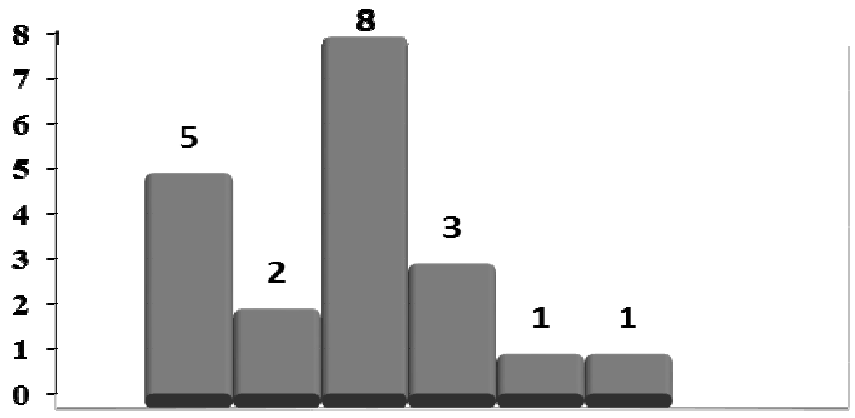

Figure 4. Histogram of the Results of Hijaiyah Letter Recognition of

Students with Low Cognitive Development

\section{e. Normality test}

The results of the normality analysis for each sub-group can be explained in the table as follows:

Table 1. Summary of Normality Test Results with Analysis Techniques Lilliefors

\begin{tabular}{|c|c|c|c|}
\hline Group & $L-$ count & $\mathrm{L}-$ table $=0.05$ & Conclusion \\
\hline A1 & 0.17 & \multirow[t]{4}{*}{0.20} & Ho: Accepted, Normal \\
\hline$A_{2}$ & 0.19 & & Ho : Accepted, Normal \\
\hline B1 & 0.14 & & Ho : Accepted, Normal \\
\hline B2 & 0.19 & & Ho : Accepted, Normal \\
\hline$A_{1} B_{1}$ & 0.18 & \multirow[t]{4}{*}{0.28} & Ho : Accepted, Normal \\
\hline A1B2 & 0.13 & & Ho : Accepted, Normal \\
\hline$A_{2} B_{1}$ & 0.14 & & Ho : Accepted, Normal \\
\hline $\mathrm{A}_{2} \mathrm{~B} 2$ & 0.27 & & Ho: Accepted, Normal \\
\hline
\end{tabular}


The conclusion from all the data from the normality test of the data groups above can be concluded that all samples come from populations that are normally distributed because all L-count $<$ L-table.

\section{f. Homogeneity Test}

The homogeneity test was carried out on each sample sub-group, namely: (A1B1), (A1B2), (A2B1), (A2B2). The summary of the results of the homogeneity analysis can be seen in the following table:

Table 2. Summary of Homogeneity Test Results

\begin{tabular}{|c|c|c|c|c|c|c|c|c|}
\hline Group & Dk & $S^{2}$ & dk.Si ${ }^{2}$ & $\log S^{2} i$ & dk. $\log S i^{2}$ & $X^{2}$ count & $\begin{array}{c}\mathrm{X}^{2} \\
\text { table }\end{array}$ & \\
\hline$A_{1}$ & 19 & 201.05 & 3820 & 2.30 & 43.76 & 1.21 & 7.81 & Homogen \\
\hline$A_{2}$ & 19 & 141.84 & 2695 & 2.15 & 40.88 & & & eous \\
\hline$B_{1}$ & 19 & 236.58 & 4495 & 2.37 & 45.11 & & & \\
\hline$B_{2}$ & 19 & 195.79 & 3720.00 & 2.29 & 43.54 & & & \\
\hline$A_{1} B_{1}$ & 9 & 201.11 & 1810 & 2.30 & 20.73 & 0.58 & 3.84 & Homogen \\
\hline$A_{1} B_{2}$ & 9 & 143.33 & 1290.00 & 2.16 & 19.41 & & & eous \\
\hline$A_{2} B_{1}$ & 9 & 173.33 & 1560.00 & 2.24 & 20,15 & 0.17 & & \\
\hline$A_{2} B_{2}$ & 9 & 98.89 & 890.00 & 2.00 & 17.96 & & & \\
\hline
\end{tabular}

Based on the table of homogeneity test results above, it can be concluded that all sample groups came from homogeneous populations.

\section{g. Hypothesis test}

Testing the hypothesis of this study using two-way ANOVA with $2 \times 2$ factorial, hypothesis testing can be seen in the following table:

Table 3. Summary of Variance Analysis Results

\begin{tabular}{llllll} 
Source Variance & Dk & JK & RJK & FCount & FTable \\
\cline { 4 - 5 } & & & & 0.05 \\
\hline
\end{tabular}




\begin{tabular}{|c|c|c|c|c|c|}
\hline $\begin{array}{l}\text { Between Columns } \\
\qquad(A) \text { : }\end{array}$ & 1 & 1562.5 & 1562.5 & $10.14^{* * *}$ & 4.96 \\
\hline Between Rows (B): & 1 & 902.5 & 902.5 & $5.85 * *$ & \\
\hline Interaction $(\mathrm{A} \times \mathrm{B})$ & 1 & 3085 & 3085 & $20.01 * *$ & \\
\hline $\begin{array}{c}\text { Between Groups A } \\
\text { and B }\end{array}$ & 3 & 2527.5 & 842.5 & $5.46 * *$ & 3.71 \\
\hline $\begin{array}{c}\text { In Groups } \\
\text { (Between Cells) }\end{array}$ & 36 & 5550 & 154.17 & & \\
\hline Total Reduction & 39 & 8077.5 & & & \\
\hline
\end{tabular}

\section{- First Hypothesis}

The statistical hypotheses tested were:

$$
\begin{aligned}
& \text { Ho : A1A2 } \\
& \text { Ha : A1 >A2 }
\end{aligned}
$$

Based on the results of proving the first hypothesis, it is found that: There is an influence between the results of the ability to read the introduction of the hijaiyah letter of students who are taught by the AlBayan learning method and students who are taught by the Iqra' learning method.

Then the Tukey test was carried out. Based on the Tukey test carried out in the appendix, it was obtained that Q1 (A1 and A2)count > Qtable where Qcount $=4.50$ and Qtable $=2.86$. Thus, it can be concluded that the overall result of the ability to read the introduction of hijaiyah letters of students who are taught using the Al-Bayan learning method is higher than students who are taught using the lqra' learning method.

\section{- Second Hypothesis}

The statistical hypotheses tested were: 


$$
\begin{aligned}
& \text { Ho : B1B2 } \\
& \text { Ha : B1 >B2 }
\end{aligned}
$$

Based on the results of the $F$ test analysis contained in the summary The results of ANOVA, obtained the value of Fcount $=5.85$, it is known that the value in Ftable is at the level $(\alpha=0.05)=4.96$. Furthermore, by comparing Fcount with Ftable to determine the criteria for acceptance and rejection of Ho, it is known that the coefficient value of Fcount>Ftable based on the previous provisions then rejects Ho and accepts Ha.

Then the Tukey test was carried out. Based on the Tukey test carried out in the appendix, it was obtained that Q1(A1 and A2)count > Qtable where Qcount $=3.42$ and Qtable $=2.86$. Thus it can be concluded that the overall result of the ability to read the introduction of hijaiyah letters of students who have high cognitive development is higher than students who have low cognitive development.

\section{- Third Hypothesis}

The statistical hypotheses tested were:

$$
\begin{aligned}
& \text { Ho: } \mathrm{A} \times \mathrm{B}=0 \\
& \mathrm{Ha}: \mathrm{A} \times \mathrm{B} 0
\end{aligned}
$$

Based on the previous provisions, reject $\mathrm{HO}$ and Accept $\mathrm{Ha}$. It can be said that: There is an interaction between the learning methods used on the results of the ability to read the introduction of hijaiyah letters of students who have high and low cognitive development.

After analyzing the F test and Tukey's test on the first hypothesis, and second, the researcher then analyzed the fourth hypothesis. Based on 
the results of the $\mathrm{F}$ test analysis contained in the summary of the previous ANOVA results, obtained the value of Fcount $=20.01$ and Ftable at the level $(\alpha=0.05)=4.96$ to determine the criteria for acceptance and rejection of Ho. Furthermore, by looking at the value of Fcount as the result of the interaction to determine the criteria for acceptance and rejection of $\mathrm{HO}$, and it is known that the value of INT. AXB 0.

Based on the previous provisions, reject $\mathrm{HO}$ and Accept $\mathrm{Ha}$. It can be said that: There is an interaction between the learning methods used on the results of the ability to read the introduction of hijaiyah letters of students who have high and low cognitive development.

\section{Discussion}

The findings of the first hypothesis give the conclusion that: there is an effect on the results of students ability to read the introduction of hijaiyah letters who are taught using the Al-Bayan learning method better than students who are taught using the lqra' learning method. This is in accordance with the findings of Eko Setiawan (2020:17) that the application of the Al-Bayan method can improve the early reading ability of the Qur'an for children aged 4-5 years at RA Ar Rohman Batu City. This is also in line with the research results of Diana, et al $(2019,95)$ that the Al-Bayan Method is one of the methods developed to facilitate the teaching of the Qur'anic material and students can improve their ability to read and memorize the Qur'an properly in accordance with the law of recitation. Therefore, the Al-Bayan method uses the school age level and the number of meetings as a benchmark for learning. The advantage of this method is that the meeting time can be shortened if you only want to master how to read in short. Especially for the initial mastery of the ability to read the Qur'an. 
Thus, the Al-Bayan Method is very appropriate to be taught to children at the age of 4-5 years, as this method was previously designed. In addition, to provide reinforcement for the results of learning to read the beginning of the Qur'an at the end of each meeting, exercises are given which are adopted from pieces of the verses of the Qur'an and have been adjusted by marking according to the learning materials being taught. For beginners, it is made easier by visualizing illustrations on each hijaiyyah letter, for example (the letter Nun (ن) "pointing" accompanied by a picture of "pointing hand"), the letter Syin (ش) ("syrup" accompanied by a picture of "syrup", etc. ). Based on the explanation, children will be easy to be invited to imagine, by learning to imagine it will be easy for children to concentrate. With good concentration,A child's brain is like a candle that must be lit in order to be able to illuminate itself (Khadijah 2016).

This first hypothesis is also in line with what was stated by Piaget and Vigotsky. Piaget explained that the interaction between students and teachers and their peer groups is very important. Because students cognitive development will occur in interactions between students and their peer groups rather than with people who are more mature.Similarly, Vgotsky in Bahri (2010:276) states that skills in mental functioning develop through direct social interaction.

In the teaching and learning process, it is expected that there will be communication in many directions that will allow for the expected activity or critical thinking power. Critical as a dimension of actualization of scientific thinking, it really contributes greatly to efforts to identify, understand, develop individuals who are innovative, dynamic, and responsible. This can be seen in the Al-Bayan learning method that students are required to provide opportunities for student-centered, 
more collaborative learning, students are actively involved in completing projects both individually and in groups to build knowledge and produce real products. So in this learning, students carry out activities with friends by involving students in the problem solving process by doing meaningful tasks, engaging in collaborative projects that integrate various materials in a meaningful way such as conducting observations, interviews, experiments and others.

\section{Conclusion}

Based on the discussion that has been described previously, several conclusions can be drawn including the following:

1. There is an influence on the ability to read the initial hijaiyah letters taught by the Al-Bayan method compared to children who are taught by the Iqra' method at the Pembina Rantau State Kindergarten, Aceh Tamiang Regency. Where the results of reading the initial hijaiyah letters of students who are taught using the Al-Bayan learning method with an average value of 67.00 are higher than students who are taught using the Iqra' learning method with an average value of 54.50.

2. There is an effect of reading results of children who have higher cognitive development than children with low cognitive development. Where the average value of the results of early reading of hijaiyah letters of students with high cognitive development is 65.50 , while the average value of reading results of early hijaiyah letters of students with low cognitive development is 58.00 . 
3. There is a significant interaction between learning methods and students cognitive development on the results of reading the initial hijaiyah letter which has cognitive development in group B of the Overseas Pembina State Kindergarten. Where there is an interaction with Fcount (20.01) > Ftable (4.96).

\section{Bibliography}

Helmawati, (2018). Mengenal dan Memahami PAUD. Bandung: PT Remaja Rodakarya

Hidayat El-Bantany, Rian. (2014). Kamus Pengetahuan Islam Lengkap. Depok: Mutiara Allamah Utama.

Khadijah, (2016). Pengembangan Kognitif Anak Usia Dini. Medan: Perdana Publishing

Putra, Sunan dan Dwi Lestari, Ninin. (2012). Penelitian Kualitatif PAUD. Jakarta: Rajawali Pres

Rakimahwati. (2012). Model Pembelajaran Sambil Bermain Pada Pendidikan Anak Usia Dini. Padang: UNP Press

Suhada, Idad. (2016). Psikologi Perkembangan Anak Usia Dini (Raudhatul Athfal). Bandung: PT Remaja Rosdakarya

Surasman, Otong. (2008). Metode Al-Bayan Cara Cepat Belajar Membaca Al-Qur'an. Jakarta: Erlangga

Suryana, Dadan. (2016). Pendidikan Anak Usia Dini Stimulasi dan Aspek Perkembangan Anak. Jakarta: Kencana

Syarbini, Amirullah dan Al-kautsar, Abu Mufidah. (2010). 5 Langkah Lancar Membaca Al-Qur'an. Bandung: Ruang Kata.

Zamani, Zaki. (2014). Tuntutan Belajar Tajwid Bagi Pemula. Yogyakarta: Mutiara Media. 